\title{
Accumulation of nitrite in hemolymph of Penaeus japonicus
}

\author{
Jiann-Chu Chen, Sheue-Feng Chen
}

Department of Aquaculture, National Taiwan Ocean University, Keelung, Taiwan 20224, Republic of China

\begin{abstract}
Penaeus japonicus (12.2 to $16.7 \mathrm{~g}$ ) were exposed individually in $25 \mathrm{ppt}$ salinity seawater to $2,4,8$ and $20 \mathrm{mg}$ nitrite- $\mathrm{N}^{-1}$ at $20 \pm 1{ }^{\circ} \mathrm{C}$; additional trials were run using 5,20 and $50 \mathrm{mg}$ nitrite- $\mathrm{N}^{-1}$. Hemolymph nitrite values for control (unexposed) shrimp weighing $12.15 \pm 0.62 \mathrm{~g}$ and $16.69 \pm$ $2.98 \mathrm{~g}$ were $0.152 \pm 0.003$ and $0.109 \pm 0.015 \mu \mathrm{g}$ nitrite $-\mathrm{N}$ $\mathrm{ml}^{-1}$, respectively. Hemolymph nitrite- $\mathrm{N}$ of shrimp exposed to $2 \mathrm{mg}$ nitrite $-\mathrm{N} \mathrm{ml}^{-1}$ was significantly higher $(\mathrm{p}<0.01$ ) than that of controls after $1 / 2 \mathrm{~h}$ exposure. Hemolymph nitrite- $\mathrm{N}$ of shrimp increased with increasing seawater nitrite-N. Hemolymph nitrite- $\mathrm{N}$ displayed a positive linear relationship with time, whereas seawater nitrite- $N$ was negatively related to time. Shrimp exposed to 2,4 and $20 \mathrm{mg}$ nitrite- $\mathrm{N}^{-1}$ accumulated nitrite- $\mathrm{N}$ in hemolymph up to $2.291,6.088$ and $25.060 \mu \mathrm{g}$ $\mathrm{ml}^{-1}$, respectively, after $16 \mathrm{~h}$, while seawater nitrite-N declined to $0.089,0.118$ and $0.257 \mathrm{mg} \mathrm{l}^{-1}$.
\end{abstract}

Nitrite, an intermediate product of ammonia during nitrification, was found to accumulate at concentrations of up to 0.12 and $4.61 \mathrm{mg}$ nitrite- $\mathrm{N}^{-1}$ in a hatchery and a growout farm, respectively, even with frequent water replacement (Chen et al. 1986, 1989). Therefore, accumulation of nitrite and its toxic effect are a primary concern.

Toxicity of nitrite to finfish and crustaceans has been widely studied, and has been reviewed by Colt \& Armstrong (1981) and Lewis \& Morris (1986). Accumulation of nitrite in the water may retard shrimp growth, enhance molting and in extreme cases cause death (Chen \& Chen 1992). This report describes nitrite accumulation in the hemolymph of Penaeus japonicus exposed to different levels of nitrite in the laboratory.

Materials and methods. Penaeus japonicus were obtained from a private growout farm, acclimated in the laboratory for $3 \mathrm{~d}$ and fed commercial shrimp feed (Tairoun Product Co., Taipei) once a day at a rate of $5 \%$ of body weight $\mathrm{d}^{-1}$. For $2 \mathrm{~d}$ prior to the experiment, the shrimp were not fed. The animals used had total lengths of $11.57 \pm 0.58 \mathrm{~cm}$ and $12.67 \pm 0.82 \mathrm{~cm}$ (mean $\pm \mathrm{SD}$ ), and weighed $12.15 \pm 0.62 \mathrm{~g}$ and $16.69 \pm 2.98 \mathrm{~g}$ (mean $\pm \mathrm{SD}$ ), for the first and second tests, respectively (see below).

Seawater pumped from the Keelung coast was filtered through a sand and gravel bed and salinity was adjusted to $25 \mathrm{ppt}\left(\mathrm{g} \mathrm{kg}^{-1}\right)$ with municipal water which had been dechlorinated with sodium thiosulfate; the seawater was then aerated by air-lifting for $3 \mathrm{~d}$ before use (Chen et al. 1990).

Nitrite test solutions were prepared by dissolving $493 \mathrm{~g}$ of sodium nitrite (Merck reagent grade) in $10 \mathrm{l}$ distilled water to obtain $10000 \mathrm{mg}$ nitrite- $\mathrm{Nl}^{-1}$, and then diluted to desired concentrations with seawater. Nitrite$N$ concentrations were 2, 4,8 and $20 \mathrm{mg} \mathrm{l}^{-1}$ and 5, 20 and $50 \mathrm{mg} \mathrm{l}^{-1}$ for the first and second tests, respectively, under conditions of 25 ppt salinity and $20 \pm 1{ }^{\circ} \mathrm{C}$.

The starved intermolt shrimp were collected randomly from the holding tanks and individually transferred to 201 circular plastic tanks containing $10 \mathrm{l}$ test solution, each of which contained a test group. Each test treatment was conducted in triplicate, and each solution was aerated using an air blower attached to a diffuser. The numbers of shrimp used in the first and second tests were 93 and 48, respectively. Each tank was covered with a plastic cap to prevent shrimp from escaping.

For the second test, 4 tanks (control, 5, 20 and $50 \mathrm{mg}$ nitrite- $\mathrm{N}^{-1}$ ) without shrimp were set up in addition to the exposure tanks described above, in order to manitor water concentrations of nitrite in the absence of shrimp. These tanks (termed 'blanks') were identical to the exposure tanks except for the presence of shrimp.

Water temperature, measured with a mercury thermometer, was maintained at $20 \pm 1^{\circ} \mathrm{C}$. Dissolved oxygen, measured with a Delta Scientific 2110 DO meter (Delta Company, USA) was kept at $5.46 \pm 0.60 \mathrm{mg}^{-1}$.

Shrimp were sampled at time intervals of $1 / 2,1,2,4,8$ and $16 \mathrm{~h}$ and $4,8,12$ and $16 \mathrm{~h}$ for the first and second tests respectively. Seawater concentrations of nitrite- $\mathrm{N}$ were verified using the method described by Strickland \& Parsons (1972). Hemolymph samples were taken by syringe from the pericardial cavities through the ends of the rostra. Zinc sulfate solution and sodium hydroxide solution were added to the hemolymph, precipitated protein was removed by centrifugation at $15000 \mathrm{rpm}$ for 2 min, and the supernatant was analyzed for nitrite-N using the method described by Schechter et al. (1972).

All data were subjected to 1-way analysis of variance (Steel \& Torrie 1980). If significant differences were indicated at the 0.05 level, then Duncan's Multiple 
Range Test was used to identify significant differences between treatments (Duncan 1955). Relationships between hemolymph nitrite and time, seawater nitrite and time, hemolymph nitrite and initial nitrite, and seawater nitrite and initial nitrite were calculated.

Results. Shrimp exposed to 2, 4, 5, 8, 20, $50 \mathrm{mg}$ nitrite- $\mathrm{N}^{-1}$ and the corresponding control individuals survived $16 \mathrm{~h}$ exposure.

In the control treatments, hemolymph nitrite- $N$ ranged from 0.148 to $0.156 \mu \mathrm{g} \mathrm{ml}^{-1}$ with an average of $0.152 \pm 0.003 \mu \mathrm{g} \mathrm{ml}^{-1}$, and from 0.133 to $0.095 \mu \mathrm{g} \mathrm{ml}^{-1}$ with an average of $0.109 \pm 0.015 \mu \mathrm{g} \mathrm{ml}^{-1}$, for the first and second tests respectively (Table 1). However, for shrimp in seawater containing $2,4,8$ and $20 \mathrm{mg}$ nitrite$\mathrm{N}^{-1}$, hemolymph nitrite- $\mathrm{N}$ increased to $2.291,6.088$, 9.411 and $25.060 \mu \mathrm{g} \mathrm{ml}^{-1}$ after $16 \mathrm{~h}$ (Table 1 ).

Hemolymph nitrite- $\mathrm{N}$ concentrations from all treatments except for the control increased over time and were higher than the original ambient concentrations after $16 \mathrm{~h}$.

Seawater nitrite- $\mathrm{N}$ concentration decreased with time and was less than half of the original concentration in all test solutions after $4 \mathrm{~h}$, except in the control (Table 2). Seawater nitrite- $N$ concentrations were $0.205,0.315$ and $2.770 \mathrm{mg} \mathrm{l}^{-1}$ after $16 \mathrm{~h}$ in the 5 , 20 and $50 \mathrm{mg} \mathrm{l}^{-1}$ test solutions containing individual shrimp. However, in the blank group, ambient nitrite- $N$ concentrations were $3.96,17.26$ and $47.92 \mathrm{mg}$ nitrite- $\mathrm{N}$ $\mathrm{I}^{-1}$ after $16 \mathrm{~h}$ (Table 2 ).

Mean hemolymph nitrite- $N$ of individual Penaeus japonicus exposed to each test solution displayed a positive linear relationship with time elapsed. However, concentration of seawater nitrite- $N$ was negatively related to time (Table 3 ).

When Penaeus japonicus were exposed to increasing levels of ambient nitrite- $N$, hemolymph nitrite- $N$ increased significantly $(\mathrm{p}<0.01)$ after $1 / 2 \mathrm{~h}$ and $4 \mathrm{~h}$ in the first and second tests, respectively (Table 1). Hemolymph nitrite- $N$ concentrations after each exposure time were positively correlated with initial nitrite$N$ concentration in each test solution, and seawater nitrite- $N$ concentrations were positively correlated with initial concentration of nitrite- $\mathrm{N}$ in each test solution at each sampling (Table 3)

Discussion. The major toxic action of nitrite in teleost blood is oxidation of hemoglobin to methemoglobin, which is incapable of binding oxygen, resulting in hypoxia and cyanosis (Bowser et al. 1983, Almendras 1987). The same reaction may occur in hemocyanincontaining shrimps, although several studies have reported that hemocyanin is still able to bind oxygen in the presence of nitrite (Needham 1961, Gutzmer \& Tomasso 1985, Jensen 1990).

Nitrite enters an organism's blood via diffusion from ambient water or metabolic production, and nitrite con-

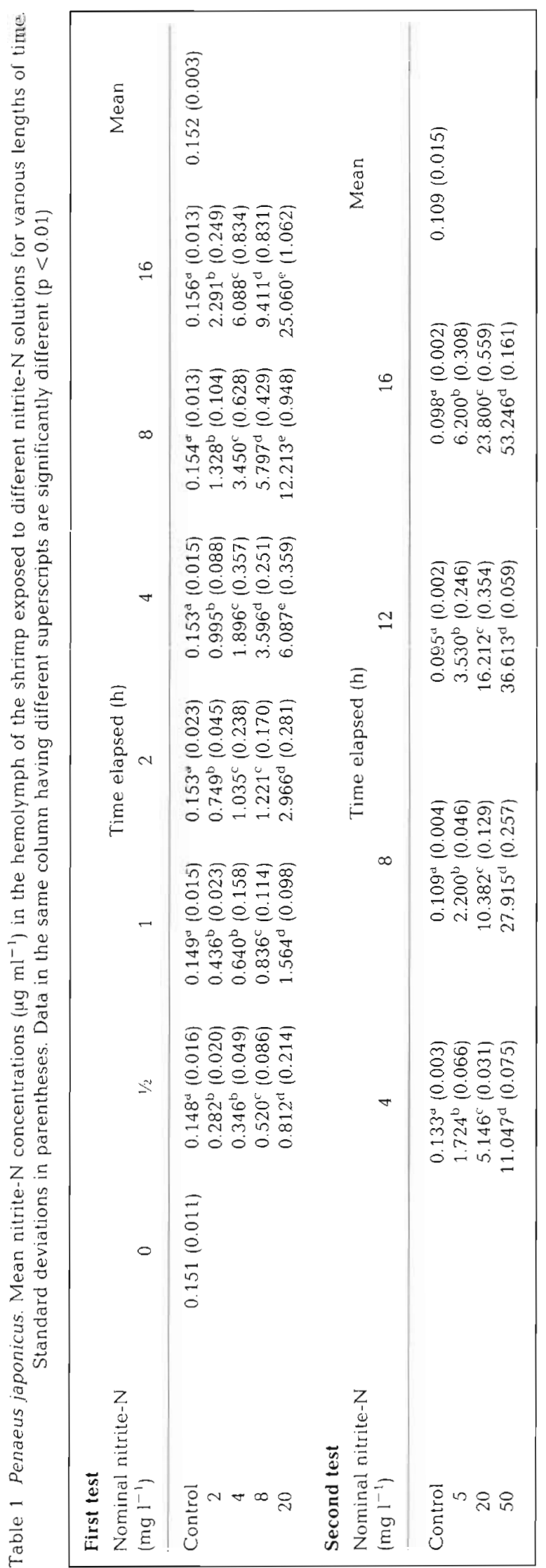


Table 2. Penaeus japonicus. Mean seawater nitrate- $\mathrm{N}$ concentrations ( $\mathrm{mg} \mathrm{l}^{-1}$ ) in the blank (B, without shrimp) and test ( $\left.\mathrm{T}\right)$ tanks, in which shrimp were exposed individually to different solutions for various lengths of time. Standard deviations in parentheses

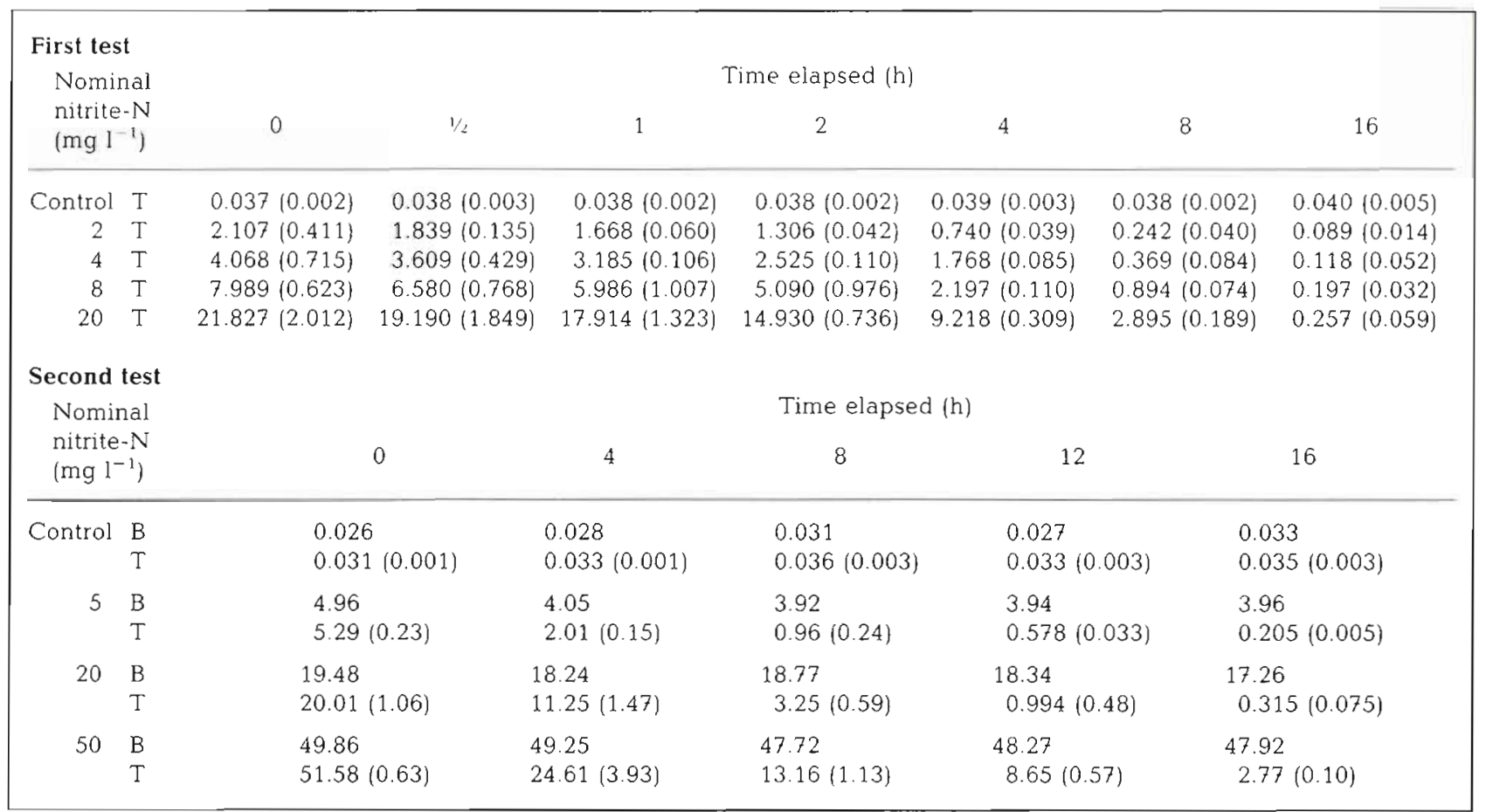

Table 3. Penaeus japonicus. Relationship of hemolymph nitrite-N concentration (HN, in $\mu g \mathrm{ml}^{-1}$ ) and seawater nitrite-N (SN, in $\left.\mathrm{mg} \mathrm{l}^{-1}\right)$ to time elapsed $(T$, in $h)$ and initial nitrite- $N$ concentrations $\left(C\right.$, in $\left.\mathrm{mg} \mathrm{l}^{-1}\right)$ to which shrimp were exposed. R: correlation coefficient

\begin{tabular}{|c|c|c|c|c|}
\hline $\begin{array}{l}\text { Nominal } \\
\text { nitrite-N (mg l-1) }\end{array}$ & Hemolymph nitrite- $N$ & $R$ & Seawater nitrite-N & $\mathrm{R}$ \\
\hline \multicolumn{5}{|l|}{ First test } \\
\hline 2 & $\mathrm{HN}=0.320+0.127 \mathrm{~T}$ & 0.985 & $\mathrm{SN}=1.693-0.123 \mathrm{~T}$ & 0.888 \\
\hline 4 & $\mathrm{HN}=0.269+0.372 \mathrm{~T}$ & 0.998 & $\mathrm{SN}=3.327-0.243 T$ & 0.903 \\
\hline 8 & $\mathrm{HN}=0.415+0.591 \mathrm{~T}$ & 0.989 & $\mathrm{SN}=6.201-0.459 \mathrm{~T}$ & 0.875 \\
\hline 20 & $\mathrm{HN}=-0.038+1.559 T$ & 0.999 & $\mathrm{SN}=18.331-1.336 \mathrm{~T}$ & 0.921 \\
\hline \multicolumn{5}{|l|}{ Second test } \\
\hline 5 & $\mathrm{HN}=-0.276+0.369 T$ & 0.949 & $\mathrm{SN}=4.129-0.290 \mathrm{~T}$ & 0.891 \\
\hline 20 & $\mathrm{HN}=-1.563+1.545 \mathrm{~T}$ & 0.996 & $\mathrm{SN}=17.093-1.241 \mathrm{~T}$ & 0.935 \\
\hline 50 & $\mathrm{HN}=-1.619+3.382 T$ & 0.993 & $\mathrm{SN}=42.870-2.840 \mathrm{~T}$ & 0.930 \\
\hline Time elapsed (h) & Hemolymph nitrite-N & $\mathrm{R}$ & Seawater nitrite-N & $\mathrm{R}$ \\
\hline \multicolumn{5}{|l|}{ First test } \\
\hline $1 / 2$ & $\mathrm{HN}=0.214+0.029 \mathrm{C}$ & 0.978 & $S N=-0.074+0.878 C$ & 0.999 \\
\hline 1 & $\mathrm{HN}=0.290+0.060 \mathrm{C}$ & 0.983 & $\mathrm{SN}=-0.163+0.822 \mathrm{C}$ & 0.999 \\
\hline 2 & $\mathrm{HN}=0.361+0.120 \mathrm{C}$ & 0.988 & $\mathrm{SN}=-0.178+0.688 C$ & 0.999 \\
\hline 4 & $\mathrm{HN}=0.642+0.264 \mathrm{C}$ & 0.974 & $\mathrm{SN}=-0.239+0.421 \mathrm{C}$ & 0.990 \\
\hline 8 & $\mathrm{HN}=0.661+0.545 \mathrm{C}$ & 0.991 & $\mathrm{SN}=-0.077+0.134 \mathrm{C}$ & 0.997 \\
\hline 16 & $\mathrm{HN}=0.434+1.134 \mathrm{C}$ & 0.998 & $\mathrm{SN}=0.073+0.009 \mathrm{C}$ & 0.931 \\
\hline \multicolumn{5}{|l|}{ Second test } \\
\hline 4 & $\mathrm{HN}=0.514+0.208 \mathrm{C}$ & 0.997 & $\mathrm{SN}=0.205+0.482 C$ & 0.996 \\
\hline 8 & $\mathrm{HN}=-0.340+0.546 \mathrm{C}$ & 0.999 & $\mathrm{SN}=-0.595+0.257 \mathrm{C}$ & 0.989 \\
\hline 12 & $\mathrm{HN}=0.425+0.712 \mathrm{C}$ & 0.998 & $\mathrm{SN}=-0.639+0.169 \mathrm{C}$ & 0.956 \\
\hline 16 & $\mathrm{HN}=1.096+1.027 \mathrm{C}$ & 0.998 & $\mathrm{SN}=-0.200+0.054 C$ & 0.957 \\
\hline
\end{tabular}


centration in the blood is a principal feature for assessing physiological functioning. Bath \& Eddy (1980) indicated that nitrite in the blood plasma of rainbow troüt Salmo gairdneri exposed to $0.7 \mathrm{mM}$ nitrite after 24 h was $5 \mathrm{mM}$. Jensen (1990) reported that hemolymph nitrite of freshwater crayfish Astacus astacus exposed to $0.8 \mathrm{mM}$ nitrite reached 8 to $10 \mathrm{mM}$ within $2 \mathrm{~d}$.

In addition to intake through the diet, most fish are able to accumulate ions through an active uptake mechanism associated with the branchial chloride cells (Bath \& Eddy 1980). Eddy et al. (1983) reported that nitrite in Salmo gairdneri blood plasma could reach 10 times the concentrations in the surrounding medium, if the fish were exposed to $0.7 \mathrm{mM}$ nitrite for $24 \mathrm{~h}$ in freshwater. However, nitrite in the blood plasma reached only one third the concentration in the surrounding medium if Atlantic salmon Salmo salar were exposed to $22.5 \mathrm{mM}$ in $16 \mathrm{ppt}$ salinity seawater. Using crayfish Procambarus clarkii, Gützmer \& Tomasso (1985) demonstrated that chloride partially inhibits nitrite from entring the circulatory system.

Wise \& Tomasso (1989) found that concentration of nitrite in plasma of red drum Sciaenops ocellatus exposed to ambient nitrite- $\mathrm{N}$ at 5.1 and $9.1 \mathrm{mg} \mathrm{l}^{-1}$ increased with increasing exposure time over $48 \mathrm{~h}$. In the present study, the fact that hemolymph nitrite-N concentration was higher after $16 \mathrm{~h}$ than the original ambient concentration in seawater containing individual Penaeus japonicus, and that the concentration of seawater nitrite- $\mathrm{N}$ decreased to less than half of the original concentration after $4 \mathrm{~h}$ exposure, suggests that once nitrite appears in the water, it is incorporated rapidly into the hemolymph of shrimp.

Jensen (1990) reported that hemocyanin decreased, and hemolymph nitrite increased, with time as Astacus astacus was exposed to $0.8 \mathrm{mM}$ nitrite for $7 \mathrm{~d}$. In the present study, it was found that once Penaeus japonicus was exposed to ambient nitrite, nitrite was incorporated into the hemolymph readily and might reduce hemocyanin concentration. Unfortunately, respiratory protein-hemocyanin and total protein in the hemolymph of shrimp were not measured quantitatively in this study. Further research is needed to clarify the oxygen carrying capacity of hemocyanin at different levels of ambient nitrite.

Acknowledgements. This is a partial result of research supported by the National Science Council (Project No. NSC 790209-B019-04). We thank Mr C. C. Hsu and Mr C. C. Lin for providing the shrimp and feed. Thanks are also due to $\mathrm{Mr}$ P. C. Liu and Mr C. Y Lin for their enthusiastic assistance.

This note was submitted to the editor

\section{LITERATURE CITED}

Almendras, M. E. (1987). Acute nitrite toxicity and methemoglobinemia in juvenile milkfish (Chanos chanos Forsskal). Aquaculture 61. 33-40

Bath, R. N., Eddy, F. B. (1980). Transport of nitrite across fish gills. J. exp. Zool. 214: 119-121

Bowser, P. R., Falls, W. W., VanZandt, J., Collier, N., Phillips, J. D. (1983). Methemoglobinemia in channel catfish of prevention. Prog. Fish Cult. 45: 154-158

Chen, J. C., Chen, S. F. (1992). Effect of nitrite on growth and molting of Penaeus monodon juveniles. Comp. Biochem. Physiol. C (in press)

Chen, J. C., Chin, I S., Lee, C. K. (1986). Effects of ammonia and nitrite on larval development of the shrimp Penaeus monodon. In: Maclean, J. L., Dizon, L. B., Hosillos, L. V (eds.) The First Asian Fisheries Forum. Asian Fisheries Society, Manila, p. 657-661

Chen, J. C., Liu, P. C., Lin, Y. T., Lee, C. K. (1989). Highlyintensive culture study of tiger prawn Penaeus monodon in Taiwan. In: De Pauw, N., Jaspers, E., Ackefors, H., Wilkins, N. (eds.) Aquaculture - a biotechnology in progress. Europear Aquaculiure Sociely, Bredene, Beigium, p. $377-382$

Chen, J. C., Liu, P. C., Nan, F. H. (1990). Lethal effect of nitrite to juvenile Metapenaeus ensis. J. Fish. Soc. Taiwan 17 $109-115$

Colt, J. E., Armstrong, D. A. (1981). Nitrogen toxicity to crustaceans, fish and molluscs. In: Allen, L. J., Kinney, E. C. (eds.) Proceedings of the Bio-Engineering Symposium for Fish Culture. Fish Culture Section, American Fisheries Society, Northeast Society of Conservation Engineers, Bethesda, MD, p. 34-47

Duncan, D. E. (1955). Multiple-range and multiple F test. Biometrics 11: 1-42

Eddy, F. B., Kunzlik, P. A., Bath, R. N. (1983). Uptake and loss of nitrite from the blood of rainbow trout, Salmo gairdneri Richardson and Atlantic salmon, Salmo salar L., in fresh water and in dilute sea water. J. Fish Biol. 23: 105-116

Gutzmer, M. Tomasso, J. R. (1985). Nitrite toxicity to the crayfish Procambarus clarkii. Bull. envir. Contam. Toxicol 34: $369-376$

Jensen, F. B. (1990). Sublethal physiological changes in freshwater crayfish, Astacus astacus, exposed to nitrite: haemolymph and muscle tissue electrolyte status, and haemolymph acid-base balance and gas transport. Aquat. Toxicol. 18: 51-60

Lewis, W. M. Jr, Morris, D. P. (1986). Toxicity of nitrite to fish: a review. Trans. Am. Fish. Soc. 115: 183-195

Needham, A. E. (1961). The problem of 'methaemocyanin Nature, Lond. 189: 306-307

Shechter, H., Gruener, N., Shuval, H. I. (1972). A micromethod for the determination of nitrite in blood. Anal. Chim. Acta 60: 93-99

Steel, R. G. D., Torrie, J. H. (1980). Principles and procedures of statistics. McGraw-Hill, New York

Strickland, J. D. H., Parsons, T R. (1972). A practıcal handbook of seawater analysis. Bull. Fish. Res. Bd Can. 167

Wise, D. J., Tomasso, J. R. (1989) Acute toxicity of nitrite to red drum Sciaenops ocellatus: effect of salinity. J. World Aquacult. Soc. 20: 193-198

Manuscript first received: January 17, 1992

Revised version accepted: April 27, 1992 